- FINANSE I PRAWO FINANSOWE.

- Journal of Finance and Financial Law

Grudzień/December 2020 • vol. 4(28): 65-78

http://dx.doi.org/10.18778/2391-6478.4.28.04

\title{
WPŁYW RAPORTOWANIA DANYCH \\ NIEFINANSOWYCH NA ZMNIEJSZENIE LUKI WARTOŚCI
}

\author{
mgr Alladyn Elmgasbi \\ Instytut Finansów, Wydział Ekonomiczno-Socjologiczny, Uniwersytet Łódzki
}

ORCID: https://orcid.org/0000-0002-6413-2163

\section{Streszczenie}

Różnice w postrzeganiu wartości od lat stanowią źródło konfliktu pomiędzy kierownictwem przedsiębiorstwa a inwestorami. Przyczyn rozbieżności upatrywano $w$ danych pozafinansowych. Choć zagadnienie raportowania danych niefinansowych jest szeroko poruszanym tematem $w$ literaturze przedmiotu, to początkowo nie istniały żadne wytyczne określające jak, i w jaki sposób te dane powinny być raportowane. Ponadto, publikacja tych danych miała jedynie na celu budowanie zaufania i tworzenie pozytywnego wizerunku. W niniejszym artykule przeanalizowano wpływ raportowania danych niefinansowych dotyczących ochrony środowiska na wartość przedsiębiorstwa. Za miernik wartości przedsiębiorstwa przyjęto wartość kapitalizacji rynkowej.

Słowa kluczowe: luka wartości, asymetria informacji, dane niefinansowe, standardy raportowania.

JEL Class: G32. 
WSTĘP

W obecnych czasach przedsiębiorstwa są odpowiedzialne nie tylko za ekonomiczne konsekwencje swojej działalności, ale również za wpływ na otoczenie zewnętrzne. Z perspektywy interesariuszy, osiągnięcie celów środowiskowych i społecznych przez przedsiębiorstwo jest równie istotne co osiągniecie celów finansowych [Villiers i Staden 2010: 227-240]. Wzrost znaczenia danych niefinansowych stworzył nowe problemy dla badaczy w kwestii ich identyfikacji i pomiaru.

Jak zauważa G. Urbanek, obecnie jednym z najtrudniejszych wyzwań jest wykazanie wpływu publikacji tych informacji na tworzenie wartości przedsiębiorstwa [Urbanek 2016: 339-348].

Oczekiwania inwestorów dotyczące rozwoju sprawozdawczości były ukierunkowane na zwiększenie przejrzystości, zakresu ujawnianych informacji o charakterze niefinansowym, w tym informacji pozwalających na prognozę sytuacji przedsiębiorstwa w przyszłości oraz zwiększenie publikowanych dobrowolnych ujawnień [Krasodomska: 2014: 17].

W artykule zostaną przedstawione wyniki badań na temat wpływu publikacji danych niefinansowych obejmujących zagadnienia ochrony środowiska dla spółek i grup kapitałowych notowanych na Giełdzie Papierów Wartościowych w Warszawie. Badania zostały przeprowadzone na podstawie danych panelowych za lata 2014-2018, dla których publikowane były dane niefinansowe. W analizie wykorzystano regresję panelową ze stałymi efektami, dostępną w programie GRETL.

W pracy postawiono następujące pytanie badawcze:

Czy ujawnianie informacji niefinansowych dotyczących ochrony środowiska wpływa na wartość przedsiębiorstwa?

Do powyższego pytania badawczego postawiono następującą hipotezę badawczą:

Publikacja informacji niefinansowych dotyczących ochrony środowiska ma istotny statystycznie wpływ na wartość przedsiębiorstwa.

\section{TEORIA ASYMETRII INFORMACII W KONTEKŚCIE LUKI WARTOŚCI}

Zarówno interesariusze wewnętrzni, jak i zewnętrzni wskazują na istotne różnice w postrzeganiu potencjalnych źródeł i obszarów tworzenia wartości przedsiębiorstwa. Brak zgodności pomiędzy nimi między jest spowodowany zróżnicowaniem posiadanego dostępu do informacji (asymetrii informacji). Zjawisko to wpływa na wycenę i niejednokrotnie powoduje, że wartość przedsiębiorstwa, z punktu widzenia kadry zarządzającej, przewyższa wartość rynkową oszacowaną przez 
inwestorów. Powstała różnica wskazuje na występowanie luki wartości [Blajer-Gołębiewska 2012: 9].

Na lukę wartości składa się: luka informacyjna, luka zrozumienia, luka jakościowa, luka w sprawozdawczości oraz luka percepcji [Eccles i in. 2001: 130]. Schemat występowania luki wartości i powstawania jej poszczególnych elementów przedstawia rysunek 1 .

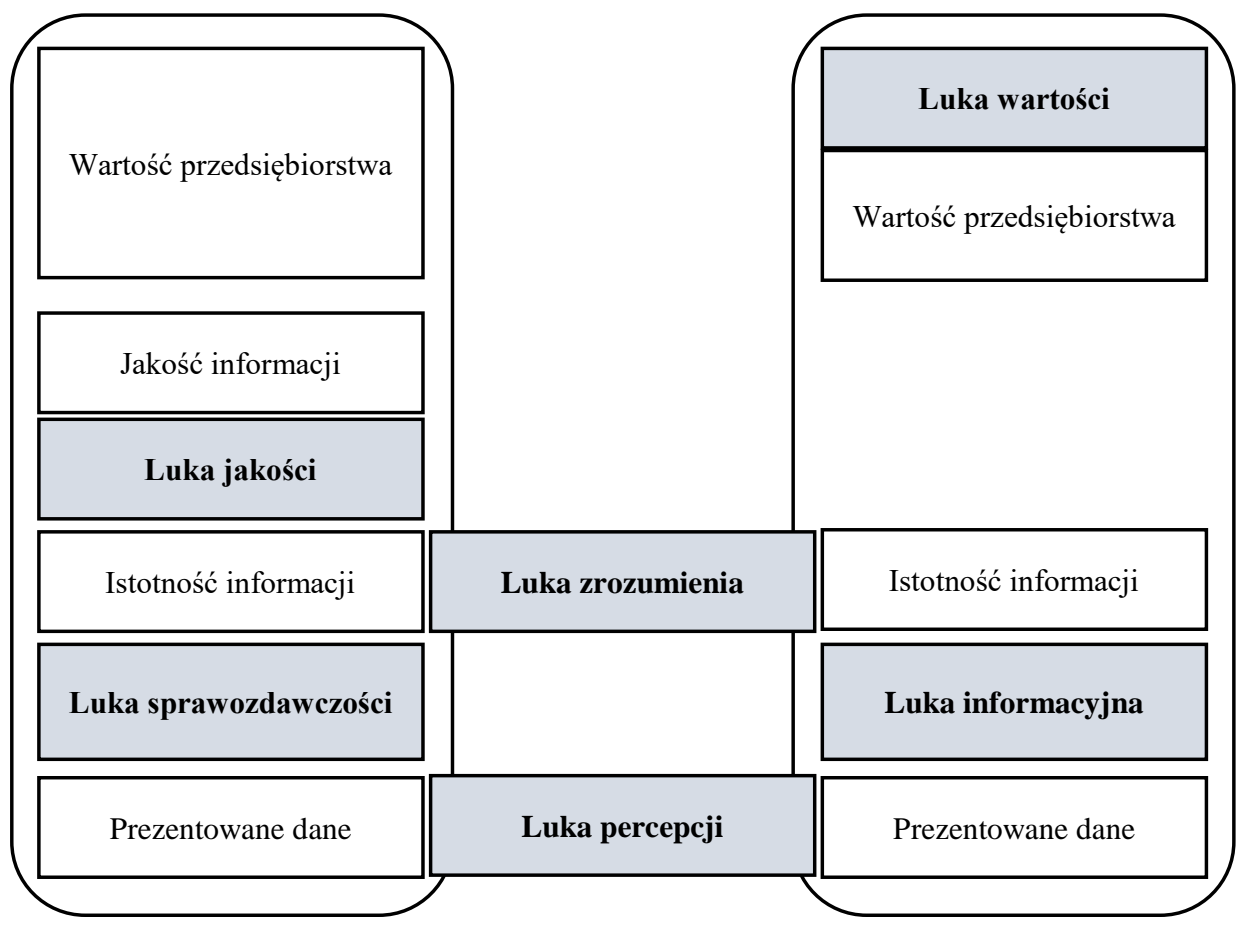

Rysunek 1. Schemat występowania luki wartości

Źródło: opracowanie własne na podstawie Mikołajewicz 2012.

Luka informacyjna (information gap) stanowi różnicę pomiędzy poziomem zaspokojenia potrzeb informacyjnych użytkownika a wagą jaka jest im przypisywana [Śnieżek i Wiatr 2016: 21-30]. Luka zrozumienia (understanding gap) stanowi różnicę pomiędzy wagą, jaką zarząd przedsiębiorstwa i inwestorzy przykładają do danego obszaru tworzącego wartość, co prowadzi do różnicy w ocenie istotności określonych wskaźników. Luka jakościowa (quality gap) to różnica w istotności, jaką zarząd spółki przypisuje danym obszarom, a poziomem wiarygodności i rzetelności informacji w nich zawartych. Luka sprawozdawczości (reporting gap) wskazuje na różnicę między poziomem znaczenia przypisywanego 
danym obszarom przez podmiot a poziomem aktywności w ich właściwym raportowaniu. Luka percepcji (perception gap) stanowi różnicę pomiędzy odczuciem zarządu przedsiębiorstwa $\mathrm{w}$ stosunku do raportowanych danych a dokładnością jego postrzegania i odbioru przez inwestorów [Przewodnik dla przedsiębiorstw, 2013: 14].

Asymetria informacji nie ogranicza się jedynie do dostępu do danych, lecz obejmuje również ograniczenia związane z przetwarzaniem i rozumieniem tych informacji [Kubiak 2003: 16]. Samo zjawisko nie powoduje wyłącznie powstawanie luki wartości, ale również generuje dodatkowe koszty. Strona będąca poszkodowaną w tej sytuacji musi dodatkowo weryfikować nowe transakcje (asymetria ex ante) i monitorować już zawarte (asymetria ex post) [Czapiewski i Kubiak 2013: 70]. Asymetria informacji ma swoje konsekwencje zarówno w skali mikro, jak i makro. Dotychczasowo omówione zagadnienia dotyczyły skali mikro. W skali makro zjawisko to związane jest z problemem efektywności rynku, gdyż wpływa na efektywność alokacji zasobów. Rynek kapitałowy uznawany jest za efektywny, gdy dostępne informacje są odzwierciedlone w cenie papierów wartościowych [Jajuga 1998: 88-89].

Jedną $\mathrm{z}$ form łagodzenia występowania asymetrii informacji jest raportowanie danych niefinansowych, w tym głównie dotyczących trzech obszarów: spraw społecznych, ochrony środowiska oraz ładu korporacyjnego [Tylec 2018: 304].

Rozwój sprawozdawczości podmiotów gospodarczych stanowi odpowiedź na rosnące potrzeby informacyjne użytkowników raportów [Śnieżek i Wiatr 2016: 22]. Jak zauważa W. Skoczylas, szerszy zakres ujawnianych informacji stanowi podstawę budowy zaufania i kreowania własnej wiarygodności. Eliminacja luki wartości przyczynia się nie tylko do wzrostu wartości rynkowej przedsiębiorstwa, ale również do poprawy wizerunku [Skoczylas 2012: 407].

\section{RAPORTOWANIE DANYCH NIEFINANSOWYCH W ŚWIETLE AKTUALNYCH PRZEPISÓW PRAWNYCH I BADAŃ}

Na przestrzeni ostatnich lat, sprawozdawczość pozafinansowa była szeroko poruszanym tematem [Marcinkowska 2004; Bek-Gaik i Krasodomska: 2018; Kawacki: 2018; Walińska $i$ in. 2018]. Informacja niefinansowa stała się jednym $\mathrm{z}$ istotnych przedmiotów dyskusji pomiędzy różnymi grupami interesariuszy [Zyznarska-Dworczak 2016: 219]. Rozwój tej dziedziny należy upatrywać w ruchach oddolnych, dokonywanych przez organizacje krajowe i międzynarodowe, jak i instytucje takie jak Komisja Europejska.

W 2014 r. w życie weszła Dyrektywa 2014/95/UE ws. ujawniania informacji niefinansowych i informacji dotyczących różnorodności. Jako jedną z przesłanek uzasadniających wprowadzenie tej Dyrektywy wskazano chęć zwiększania 
spójności i porównywalności informacji pozafinansowych ujawnianych wśród krajów UE. W Polsce, od stycznia 2017 r., obowiązują przepisy nowelizacji ustawy o rachunkowości wdrażające do polskiego prawa tę dyrektywę. Tym sposobem, od 2018 r. polskie spółki i grupy kapitałowe są zobowiązane składać oświadczenie na temat informacji niefinansowych wraz ze sprawozdaniem ze swojej działalności. Obowiązek ten ma zastosowanie tylko do dużych podmiotów, będących jednostkami zainteresowania publicznego, zatrudniających co najmniej 500 pracowników i spełniających jeden z dwóch kryteriów finansowych: $85 \mathrm{mln}$ zł sumy aktywów bilansu na koniec roku obrotowego lub $170 \mathrm{mln}$ zł przychodów netto ze sprzedaży towarów i produktów za dany rok obrotowy. Zgodnie z art. 49b ustawy o rachunkowości (UoR), oświadczenia powinny zawierać opisy stosowanych przez spółki polityk w odniesieniu do: zagadnień społecznych, spraw pracowniczych, zrównoważonego rozwoju, poszanowania praw człowieka, środowiska naturalnego i przeciwdziałaniu korupcji.

Przed wejściem w życie postanowienia Dyrektywy, w Polsce obowiązywały zasady raportowania CSR, które częściowo miały charakter dobrowolny. Warto również zaznaczyć, że w przypadku podmiotów należących do sektorów szczególnie oddziałujących na środowisko naturalne istniał obowiązek ujawniania danych niefinansowych w zakresie ochrony środowiska [Adamek-Hyska i in. 2019: 70-76].

Spółka może ustalić własne zasady raportowania bądź wykorzystać dowolne krajowe, unijne lub międzynarodowe standardy, lecz sporządzając oświadczenie lub odrębny raport niefinansowy ma ona obowiązek wskazać, z jakich zasad standardów skorzystała i muszą być one spójne z wymogami nowej Dyrektywy.

W 2017 r. Komisja Europejska opublikowała wytyczne dotyczące sprawozdawczości niefinansowej, której celem jest zwiększenie przejrzystości, a także zachęcenie przedsiębiorstw do przyjęcia bardziej zrównoważonego podejścia w kwestii prowadzonej działalności. W 2019 r. Komisja Europejska uwzględniła nowe wytyczne obejmujące zagadnienia związane z klimatem.

Najszerzej stosowanymi wytycznymi w zakresie raportowania danych niefinansowych są standardy opracowane przez międzynarodową organizację GRI ${ }^{1}$. Najnowszy standard oznaczony jest symbolem GRI Standards. Wytyczne GRI odwołują się do międzynarodowych standardów, w tym: Wytyczne OECD dla przedsiębiorstw wielonarodowych, 10 Zasad ONZ Global Compact, Wytyczne ONZ dotyczące biznesu i praw człowieka. Raport zgodny ze standardami GRI zapewnia całościowy obraz kluczowych zagadnień dla przedsiębiorstwa, ich skutków i sposobu zarządzania nimi. Organizacje mogą korzystać ze wszystkich lub $\mathrm{z}$ wybranych standardów GRI do raportowania określonych informacji.

\footnotetext{
${ }^{1}$ Global Reporting Initiative.
} 
Kolejnym standardem raportowania informacji pozafinansowych jest $\mathrm{SIN}^{2}$. Jest to oddolna inicjatywa koordynowana przez Fundację Standardów Raportowania oraz Stowarzyszenie Emitentów Giełdowych. SIN umożliwia przedsiębiorstwom wypełnienie obowiązków raportowania danych niefinansowych określonych w Dyrektywie 2014/95/UE. Standardy te mogą być stosowany nie tylko przez spółki giełdowe, ale też przez inne podmioty, w tym instytucje i organizacje. Korzystanie z SIN jest bezpłatne.

Kolejną publikacją $\mathrm{w}$ zakresie raportowania niefinansowego są wytyczne przedstawione przez IIRC ${ }^{3}$. Obejmują one zagadnienia związane z raportowaniem zintegrowanym. Raport zintegrowany łączy dane finansowe i niefinansowe w jednym dokumencie, tworząc tym samym całościowy obraz sytuacji w przedsiębiorstwie. Pomocny w przygotowaniu raportu zintegrowanego może być Przewodnik dla przedsiębiorstw wydany przez Ministerstwo Gospodarki w 2013 r. Przewodnik został opracowany z myślą o wspieraniu w budowaniu wiarygodności i transparentności.

Standaryzacja procesów raportowania danych niefinansowych przynosi wiele korzyści, zarówno dla obiorców, jak i sporządzających raport. Dane są przejrzyste i mogą być porównywane pomiędzy podmiotami. Należy jednak mieć świadomość, że wszelkie formy uogólnienia pomijają kwestie specyfiki danej branży i sektora oraz specyfiki kraju, w którym prowadzona jest działalność.

Analiza raportów spółek giełdowych wykazała, że z roku na rok lepiej i obszerniej prezentują informacje niefinansowe. Pojawia się jednak pytanie, czy rozszerzona sprawozdawczość jest wykorzystywana i czy można uznać, że publikacja informacji niefinansowych pomaga ocenić lub skorygować podjętą decyzję inwestycyjną [Cebrowska 2001: 12].

Jedna z pierwszych prac podejmujących problematykę użyteczności raportów rocznych pochodzi z 1986 r. Autorka zwraca uwagę, że ówczesne badania koncentrowały się na analizie zawartości niż na opinii ich użytkowników. Grupa odbiorców raportów rocznych jest bardzo zróżnicowana, jednak największą grupę stanowią akcjonariusze oraz analitycy finansowi, od których zależy wiele decyzji inwestycyjnych na rynkach kapitałowych [Day 1986: 295-307].

N.J.H. Lorraine, D.J. Collison i D.M. Power zwracają uwagę, że obszar badań obejmujących wpływ ujawnień informacji środowiskowych oraz społecznych na kształtowanie wartości firmy jest bardzo interesujący [Lorraine i in. 2004: 7-26].

C. de Villiers oraz C.J. van Stadek ustalili, że akcjonariusze z Wielkiej Brytanii, Stanów Zjednoczonych oraz Australii byli zainteresowani zwiększeniem ujawnień obejmujących tematy środowiskowe, społeczne i ekonomiczne [Villiers i Staden 2010: 227-240].

\footnotetext{
${ }^{2}$ Standard Informacji Niefinansowych.

${ }^{3}$ International Integrated Reporting Council.
} 
Jak podaje J. Krasodomska, liczba publikacji zajmujących się badaniem opinii użytkowników rocznych raportów wzrosła już w latach 90., przy czym wysoki wynik osiągnęła dopiero w ostatnich latach. Obecnie kluczowym problemem badawczym jest określenie istotnych elementów raportu rocznego [Krasodomska 2014: 202-240]. Dotychczasowe badania nie udzielają jednak jednoznacznej odpowiedzi na to, czy informacje zawarte w raportach spółek spełniają oczekiwania ich odbiorców [Micherda 2012: 141].

Ujawnienia informacji społecznych i środowiskowych sprzyja zmniejszaniu asymetrii informacji. Badania D. Dziawgo pokazują, że inwestorzy indywidualni przy zakupie akcji kierują się również takimi czynnikami jak: pozycja rynkowa, renoma, marka, branża i otoczenie makroekonomiczne, strategia spółki, CV członków zarządu, plany oraz przyszły inwestycje, struktura dostawców i odbiorców [Dziawgo 2011: 239-241].

Do przeciwnych wniosków doszli R. Orens i N. Lybaert, ktorzy wskazują, że inwestorzy w podejmowaniu decyzji nie wykorzystują informacji niefinansowych za wyjątkiem informacji prospektywnych oraz tych, dotyczących struktury przedsiębiorstwa [Orens i Lybaert 2007: 237-271].

Chan oraz Milne ustalili, że ujawnienia informacji z niefinansowych obszarów środowiskowych i społecznych nie wpływają na podejmowane przez inwestorów decyzje, lecz mogą być one kluczowe w sytuacji, gdy obszary te mają istotny wpływ na generowanie przyszłych przepływów pieniężnych [Milne i Chan 1999: 439-457].

\section{BADANIE}

Próba składa się z największych spółek i grup kapitałowych notowanych na Giełdzie Papierów Wartościowych w Warszawie należących do indeksów giełdowych WIG20, mWIG40 lub sWIG80. Z grupy badawczej zostały wykluczone spółki z sektorów należących do makrosektora „Finanse”, przyjmując, że podmioty te charakteryzują się inną specyfiką prowadzonej działalności, co przekłada się na inny charakter prowadzonej sprawozdawczości. Dane pozyskano ze skonsolidowanych raportów rocznych, raportów zintegrowanych i raportów CSR sporządzonych za okres 2014-2018 i udostępnionych na stronach internetowych tych podmiotów oraz stronie internetowej Stooq, z której pozyskano informacje o cenie akcji na określony dzień bilansowy podmiotów. Dane były zbierane ręcznie w okresie od lipca do października 2019 r. W rezultacie, badanie zostało przeprowadzone na próbie niezbilansowanej liczącej 90 jednostek w 5 okresach. Badania zostały przeprowadzone przy wykorzystaniu regresji panelowej ze stałymi efektami. 
Za zmienną objaśnianą, określającą wartość przedsiębiorstwa, przyjęto wartość kapitalizacji rynkowej (w mln zł), która wyznaczona jest na koniec roku obrotowego danego podmiotu. Zmienne objaśniające mają charakter zero-jedynkowy, co oznacza, że gdy spółka informuje o wielkości danego zjawiska, wyrażonego w formie ilościowej lub wartościowej, to wskaźnik przyjmuje wartość 1, a w przeciwnej sytuacji wskaźnik przyjmuje wartość 0 . Wśród zmiennych objaśniających znajdują się:

- emisja CO2 (CO2);

- zużycie energii (Energia);

- pobór wody (Woda);

- wygenerowane odpady (Odpady);

- kary i koszty środowiskowe (Srodo).

W ramach artykułu przeanalizowano wpływ zmiennych objaśniających na zmienną objaśnianą w poszczególnych makrosektorach: „Chemia i Surowce”, „Dobra Konsumpcyjne”, „Handel i Usługi”, „Ochrona Zdrowia”, „Paliwa i Energia”, „Produkcja Przemysłowa i Budowlano-Montażowa” oraz „Technologie”. W tym celu zostało stworzonych osiem modeli, oszacowanych przy błędach standardowych parametrów według odpornej heteroskedastyczności (robust HAC).

Statystyki opisowe dotyczące kapitalizacji rynkowej oraz liczba obserwacji dla poszczególnych zmiennych objaśniających zostały przedstawione w tabeli 1 .

Kapitalizacja rynkowa w określonej zbiorowości jest zróżnicowana. Najniższa wartość znajduje się w makrosektorze „Technologie” - 10,81 mln zł, a najwyższa w makrosektorze „Paliwa i Energia” - 46 256,73 mln zł. Warto również zwrócić uwagę na liczbę publikowanych informacji. Najwięcej informacji z zagadnienia ochrony środowiska zostało opublikowanych przez podmioty należące do makrosektora „Produkcja Przemysłowa i Budowlano-Montażowa”. Jest to spowodowane tym, że jest on najliczniejszy, bo składa się z 82 podmiotów. Ponadto, obok „Chemia i Surowce” oraz „Paliwa i Energia”, te trzy makrosektory charakteryzują się największym negatywnym wpływem na środowisko naturalne. Najmniej opublikowanych wybranych informacji środowiskowych odnotowano w makrosektorze „Ochrona Zdrowia”, „Technologie” oraz „Handel i Usługi”, co prawdopodobnie wiąże się z faktem, że sektory te nie oddziałują negatywnie na środowisko naturalne.

Wyniki badań regresji panelowej dla wszystkich modeli zostały przedstawione w tabeli 2.

Test Pearsona chi-kwadrat wykazał, że należy odrzucić hipotezę zerową, mówiącą o niezależności zmiennych objaśniających. W badaniu dla sektorów „Dobra Konsumpcyjne”, „Handel i Usługi”, „Ochrona Zdrowia” oraz „Technologie” program GRETL sam pominął zmienne cechujące się ścisłą współliniowością. Najczęściej wykluczaną była zmienna Srodo (informacje o karach i kosztach środowiskowych). 


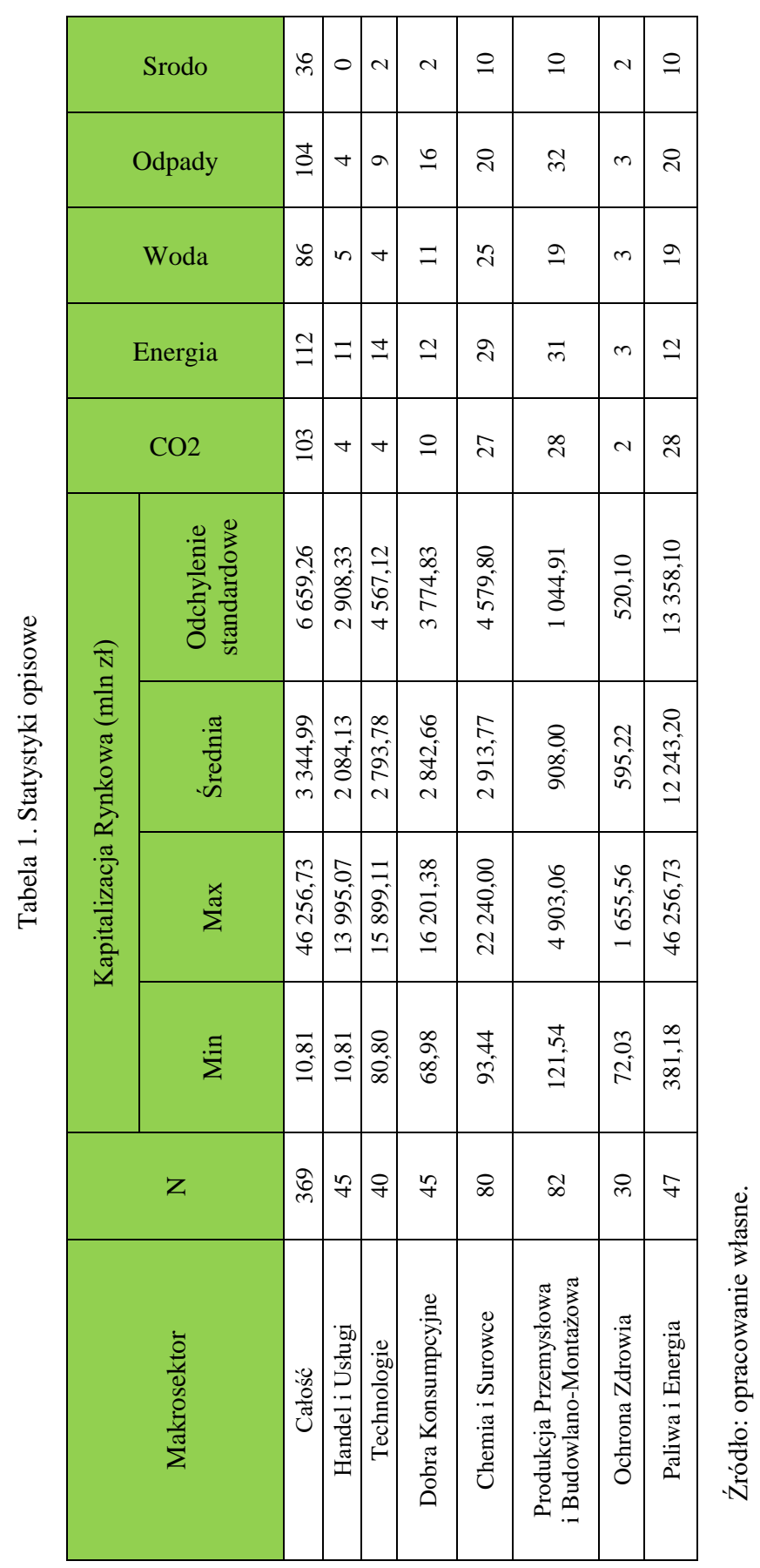




\begin{tabular}{|c|c|c|c|c|c|c|c|c|}
\hline 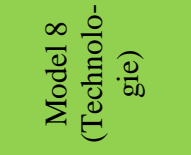 & 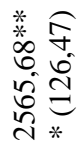 & 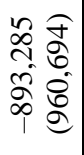 & 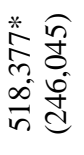 & & & & f & $\frac{\stackrel{d}{R}}{\hat{f}}$ \\
\hline 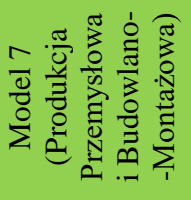 & \begin{tabular}{l}
$*$ \\
$*$ \\
$*$ \\
\multirow{2}{*}{0} \\
0 \\
0 \\
0 \\
$\infty$ \\
$\infty$
\end{tabular} & 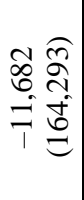 & 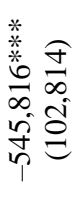 & 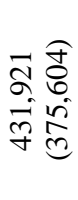 & 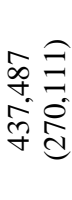 & 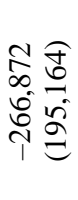 & $\infty$ & $\stackrel{\frac{2}{2}}{=}$ \\
\hline 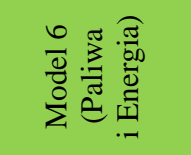 & 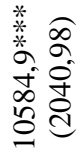 & 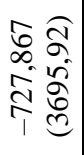 & 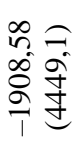 & 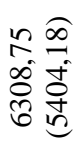 & 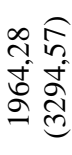 & 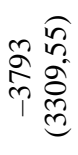 & ซ & $\begin{array}{l}8 \\
n \\
n \\
n\end{array}$ \\
\hline 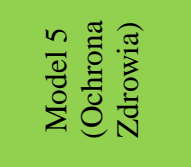 & \begin{tabular}{l}
$*$ \\
$*$ \\
\multirow{*}{*}{} \\
$\infty$ \\
$o$ \\
$\dot{0}$ \\
0
\end{tabular} & 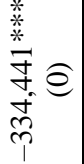 & 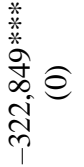 & & & & లి & 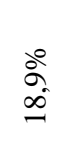 \\
\hline 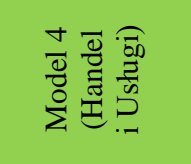 & 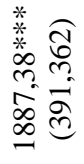 & 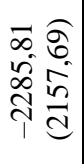 & 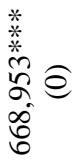 & 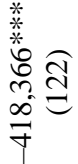 & 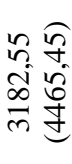 & & $\stackrel{n}{f}$ & $\begin{array}{l}\stackrel{\circ}{2} \\
\text { ๗े}\end{array}$ \\
\hline 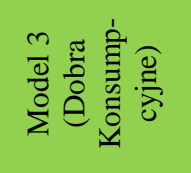 & 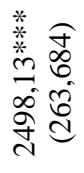 & 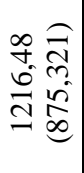 & 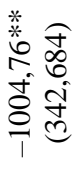 & 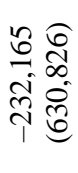 & 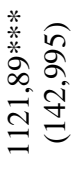 & & $\mathscr{\wp}$ & $\begin{array}{l}\stackrel{0}{a} \\
\text { ò }\end{array}$ \\
\hline 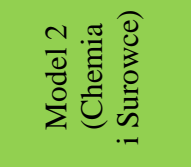 & 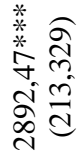 & 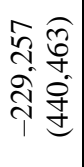 & 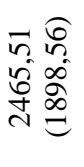 & 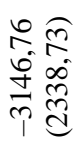 & 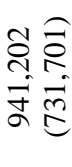 & 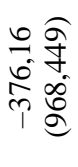 & $\infty$ & $\begin{array}{l}\infty \\
\infty \\
\infty \\
\infty\end{array}$ \\
\hline \multirow[t]{2}{*}{$\begin{array}{l}=0 \\
\overline{0} 0 \\
\frac{0}{0} \\
0 \\
\Sigma\end{array}$} & 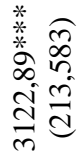 & 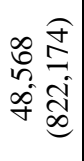 & 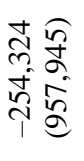 & 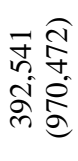 & 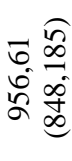 & 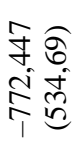 & فे & $\begin{array}{l}\stackrel{0}{2} \\
m \\
m\end{array}$ \\
\hline & 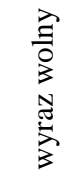 & రิ & 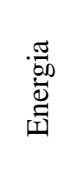 & $\begin{array}{l}\frac{\pi}{8} \\
3\end{array}$ & $\begin{array}{l}\hat{\tilde{\sigma}} \\
\hat{\tilde{0}}\end{array}$ & $\begin{array}{l}8 \\
\text { : } \\
\text { is }\end{array}$ & Z & 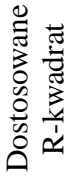 \\
\hline
\end{tabular}


Publikacja informacji o emisji dwutlenku węgla okazała się być zmienną istotną statystycznie jedynie w spółkach należących do makrosektora „Ochrona Zdrowia”. Zmienna ta wpływa negatywnie na wielkość kapitalizacji rynkowej.

Najczęściej istotna statycznie okazała się być zmienna Energia. Znaki przy parametrach wskazują, że publikacja danych o zużyciu energii ma zarówno pozytywny, jak i negatywny wpływ na zmienną objaśnianą. Negatywny wpływ zanotowały spółki z makrosektorów: „Dobra Konsumpcyjne”, „Ochrona Zdrowia”, „Produkcja Przemysłowa i Budowlano-Montażowa”. Dodatni wpływ wskazują spółki z makrosektorów „Handel i Usługi” oraz „Technologie”. Co ciekawe, zmienna ta okazała się być nieistotna dla makrosektora „Paliwa i Energia”, co oznacza, że wśród spółek energetycznych informacja o zużyciu energii nie ma wpływu na wartość wyemitowanych przez nich akcji.

Zmienna Odpady, dotycząca publikacji danych o wygenerowanych odpadach, była istotna statystycznie jedynie w modelu 3 („Dobra Konsumpcyjne”). Wraz z publikacją tych informacji rośnie wartość kapitalizacji rynkowej, co oznacza, że podmioty należące do tego makrosektora powinny dążyć do poszerzania sprawozdawczości z tego obszaru.

Informacje o karach środowiskowych (Srodo) okazały się negatywnie wpływać na kapitalizację rynkową we wszystkich modelach, lecz w żadnym nie w modelu nie była to zmienna istotna.

Związek pomiędzy charakterem prowadzonej działalności a zasięgiem oddziaływania na środowisko nie został potwierdzony w badaniach. Oczekiwałoby się, że zmienne objaśniające będą miały istotny wpływ na wartość podmiotów należących do tych sektorów, które najmocniej oddziaływują na środowisko („Paliwa i Energia”, „Chemia i Surowce”, „Produkcja Przemysłowa i Budowlano-Montażowa").

Wyjaśnienie zmienności zmiennej objaśnianej różni się pomiędzy modelami. W modelu 1 zmienność została wyjaśniona w zaledwie 3,3\%. Najwyższy wynik pojawił się w modelu 8 dla makrosektora „Technologie” - 40,7\%, a najniższy w modelu 5 dla makrosektora „Dobra konsumpcyjne”-10,9\%.

\section{PODSUMOWANIE}

Dotychczasowe oparcie sprawozdawczości przede wszystkim na danych finansowych spowodowało powstanie różnic w wycenie dokonywanej przez kadrę zarządzająca a inwestorami. Każda ze stron dostrzegała inną wartość, co doprowadziło to powstania luki [Michalczuk i Mikulska 2015: 105-112]. Z pomocą miało przyjść zwiększenie raportowania o dane pozafinansowe.

Za sprawą nowych regulacji prawnych i oddolnych inicjatyw, raportowanie danych niefinansowych na przestrzeni ostatnich lat bardzo się rozwinęło. 
Pojawiły się nowe rodzaje raportów, w tym raporty CSR i raporty zintegrowane lub rozszerzono zakres ujawnień $w$ już istniejących raportach. To zrodziło nowe obowiązki sprawozdawcze, z powodu których powstały wątpliwości dotyczące sposobu i zakresu obowiązkowych ujawnień [Szwajca i Nawrocki 2016: 299310].

Celem artykułu była weryfikacja wpływu publikacji danych niefinansowych dotyczących ochrony środowiska na wartość przedsiębiorstwa, co w konsekwencji wiązałoby się z wyznaczeniem potencjalnych generatorów i źródeł tworzenia wartości oraz ograniczeniem luki wartości. Uzyskane wyniki badań wskazują, że publikacja tych danych ma wpływ na wartość kapitalizacji rynkowej. Wpływ ten jednak waha się w przedziale od 3,3\% do 40,7\% w zależności od makrosektora GPW. W związku z powyższym, można stwierdzić, że raportowanie danych niefinansowych zmniejsza lukę wartości. Zmienne objaśniające okazały się być jednak nieistotne statystycznie w badaniu całościowym. Analizując odrębnie makrosektory udało się wskazać, że publikacja informacji dotyczących zużycia energii, wody lub wygenerowanych odpadów ma istotny wpływ na kapitalizację firm wybranych makrosektorów. Związek pomiędzy charakterem prowadzonej działalności a zasięgiem oddziaływania na środowisko nie został potwierdzony w badaniach. Oczekiwałoby się, że zmienne objaśniające będą miały istotny wpływ na wartość kapitalizacji rynkowej spółek należących do tych sektorów, które najmocniej oddziaływują na środowisko („Paliwa i Energia”, „Chemia i Surowce”, „Produkcja Przemysłowa i Budowlano-Montażowa”). Przyczyna może leżeć w niejednorodności danych, która wynika z próby przyjętej do badania. Należałoby wprowadzić dodatkowe kryterium związane np. $\mathrm{z}$ wielkością porównywanych spółek.

Dalszych kierunków badań należałoby upatrywać w analizie wpływu innych danych niefinansowych na wartość kapitalizacji rynkowej lub wyznaczyć inną zmienną objaśnianą, którą mogłaby być np. całkowita stopa zwrotu (TSR).

\section{BIBLIOGRAFIA}

Adamek-Hyska D., Strojek-Filus M., Tkocz-Wolny K., Wszelaki A., 2019, Zmiany zakresu informacyjnego raportów finansowych i niefinansowych, Wydawnictwo Uniwersytetu Ekonomicznego w Katowicach, Katowice.

Bek-Gaik B., Krasodomska J., 2018, Informacje niefinansowe jako obszar wspótczesnej sprawozdawczości przedsiębiorstw - definicja, źródta i proponowane kierunki badań, „Zeszyty Naukowe / Uniwersytet Ekonomiczny w Krakowie", vol. 23 (XXIII), issue 2(974).

Blajer-Gołębiowska A., 2012, Asymetria informacji w relacjach inwestorskich. Perspektywa nadzoru korporacyjnego, Wydawnictwo Uniwersytetu Gdańskiego, Gdańsk.

Cebrowska T., 2001, Nowe podejście do sprawozdawczości finansowej, „Zeszyty Teoretyczne Rachunkowości”, t. 4(60). 
Czapiewski L., Kubiak J., 2013, Metody określania wag w wielowymiarowej analizie porównawczej a adekwatność pomiaru poziomu asymetrii informacji, „Zeszyty Naukowe Uniwersytetu Szczecińskiego. Finanse, Rynki Finansowe, Ubezpieczenia", nr 59.

Day J.F.S., 1986, The Use of Annual Reports by UK Investment Analysts, „Accounting and Business Research", vol. 16(64), Autumn.

Dziawgo D., 2011, Relacje inwestorskie. Ewolucja - funkcjonowanie - wyzwania, Wydawnictwo Naukowe PWN, Warszawa.

Eccles R.G., Herz R.H., Keegan E.M., Phillips D.M.H., 2001, The Value Reporting Revolution. Moving Beyond The Earnings Game, PWC, John Wiley \& Sons, New York.

Giełda Papierów Wartościowych w Warszawie, https://www.gpw.pl/ [dostęp 31.03.2020].

Jajuga T., 1998, Inwestycje, instrumenty finansowe, ryzyko finansowe, inżynieria finansowa, Wydawnictwo Naukowe PWN, Warszawa.

Kawacki M., 2018, Sprawozdanie niefinansowe jako nowy raport na granicy rachunkowości, „Prace Naukowe Uniwersytetu Ekonomicznego we Wrocławiu: Współczesne problemy w nauce, dydaktyce i praktyce rachunkowości”, vol. 9, issue 503.

Komisja Europejska, Commission guidelines on non-financial reporting, https://ec.europa.eu/info/publications/non-financial-reporting-guidelines_en [dostęp 31.03.2020].

Krasodomska J., 2014, Informacje niefinansowe w sprawozdawczości spółek, Wydawnictwo Uniwersytetu Ekonomicznego w Krakowie, Kraków.

Kubiak J., 2003, Zjawisko asymetrii informacji a struktura kapitatu przedsiębiorstw w Polsce, Wydawnictwo Uniwersytetu Ekonomicznego w Poznaniu, Poznań.

Lorraine N.J.H., Collison D.J., Power D.M., 2004, An analysis of the stock market impact of environmental performance information, „Accounting Forum, Taylor \& Francis Journals”, vol. 28(1), March.

Marcinkowska M., 2004, Raport roczny z działań $i$ wyników przedsiębiorstwa. Nowe tendencje w sprawozdawczości biznesowej, Oficyna Ekonomiczna, Kraków.

Michalczuk G., Mikulska T., 2012, Znaczenie raportowania zintegrowanego w zmniejszaniu luki wartości przedsiębiorstwa, „Prace Naukowe Uniwersytetu Ekonomicznego we Wrocławiu”, nr 396.

Micherda B. (red.), 2012, Kierunki ewolucji sprawozdawczości i rewizji finansowej, Difin, Warszawa.

Mikołajewicz G., 2012, Luka wartości w kontekście sprawozdawczości przedsiębiorstwa, „Prace Naukowe Uniwersytetu Ekonomicznego we Wrocławiu", nr 261.

Milne M.J., Chan C.C.C, 1999, Narrative Corporate Social Disclosures: How Much Difference Do They Make to Investment Decision-making, „British Accounting Review”, vol. 31(4).

Orens R., Lybaert N., 2007, Does the Financial Analysts' Usage of Non-financial Information Influence the Analysts' Forecast Accuracy? Some Evidence from the Belgian Sell-side Financial Analyst, „The International Journal of Accounting”, vol. 42(3).

Przewodnik dla przedsiębiorstw, 2013, Raport Ministerstwa Gospodarki, https://www.gov.pl/ [dostęp 31.03.2020].

Strona internetowa Internetowego Systemu Aktów Prawnych, http://isap.sejm.gov.pl/isap.nsf/home.xsp. [dostęp 31.03.2020].

Skoczylas W., 2012, Innowacje w raportowaniu wyników czynnikiem poprawy efektywności podejmowanych decyzji, „Prace Naukowe Uniwersytetu Ekonomicznego we Wrocławiu”, nr 261.

Szwajca D., Nawrocki T.L., 2016, Możliwości oceny zaangażowania przedsiębiorstw w działania spotecznie odpowiedzialne a ich polityka informacyjna $w$ zakresie CSR, „Przegląd Organizacji”, $\mathrm{nr} 4$.

Stooq, https://www.stooq.pl/ [dostęp 31.03.2020]. 
Śnieżek E., Wiatr M., 2016, Modelowanie raportów jako próba ograniczenia luki komunikacyjnej w sprawozdawczości finansowej, ,Studia Ekonomiczne. Zeszyty Naukowe Uniwersytetu Ekonomicznego w Katowicach", nr 284.

The GRI Sustainability Reporting Standards, https://www.globalreporting.org/information/sustainability-reporting/Pages/gri-standards.aspx [dostęp 31.03.2020].

Tylec A., 2018, CSR jako obszar raportowania niefinansowego $w$ świetle rozszerzenia zakresu ujawnień, „Zeszyty Naukowe Politechniki Śląskiej. Seria: Organizacja i Zarządzanie”, z. 127.

Urbanek G., 2016, Marka a wartość przedsiębiorstwa na przykładzie polskich spółek giełdowych, „Finanse, Rynki Finansowe, Ubezpieczenia”, nr 1(79).

Ustawa z dnia 15 grudnia 2016 r. o zmianie ustawy o rachunkowości, Dz.U. 2017, poz. 61.

Villiers C. de, Staden C.J. van, 2010, Shareholders' requirements for corporate environmental disclosures: A cross country comparison, „The British Accounting Review”, vol. 42(4).

Walińska E., Bek-Gaik B., Gad J., 2018, Informacje finansowe i niefinansowe w raporcie zintegrowanym - praktyka spótek notowanych na Giełdzie Papierów Wartościowych w Warszawie, „Zeszyty Teoretyczne Rachunkowości”, vol. 23(XXIII), issue 156.

Zyznarska-Dworczak B., 2016, Rozwój sprawozdawczości niefinansowej a możliwość jej zewnętrznej weryfikacji, „Studia Ekonomiczne. Zeszyty Naukowe Uniwersytetu Ekonomicznego w Katowicach", $\mathrm{nr} 285$.

\title{
THE IMPACT OF NON-FINANCIAL DATA REPORTING ON REDUCTION OF VALUE GAPS
}

\begin{abstract}
Differences in the perception of value have been for years a source of conflict between the management and investors. The reason for the divergence was seen in non-financial data. Although the issue of non-financial data reporting is a widely discussed, initially there were no guidelines determining how and what should be reported. In addition, publication of this data was only intended to build trust and create a positive image. This article analyzes the impact of reporting non-financial environmental data on the value of a company, which was assumed to be the market capitalization.
\end{abstract}

Keywords: value gap, information asymmetry, non-financial data, reporting standards. 